\title{
The Effect of Traction Sanding on Urban Suspended Particles in Finland
}

Kupiainen, K.

Kluwer Academic Publishers

2004

Kupiainen, K. and Tervahattu, H. 2004. The Effect of Traction Sanding on Urban Suspended pÿParticles in Finland. Environmental Monitoring and Assessment 93: 287300.

http://hdl.handle.net/1975/242

Downloaded from Helda, University of Helsinki institutional repository.

This is an electronic reprint of the original article.

This reprint may differ from the original in pagination and typographic detail.

Please cite the original version. 


\title{
THE EFFECT OF TRACTION SANDING ON URBAN SUSPENDED PARTICLES IN FINLAND
}

\author{
KAARLE KUPIAINEN ${ }^{1,2 *}$ and HEIKKI TERVAHATTU ${ }^{1,2}$ \\ ${ }^{1}$ Department of Limnology and Environmental Protection, University of Helsinki, Helsinki, \\ Finland; ${ }^{2}$ Nordic Envicon Oy, Koetilantie 3, Helsinki, Finland \\ (* author for correspondence, e-mail: kaarle.kupiainen@helsinki.fi)
}

(Received 11 September 2002; accepted 9 May 2003)

\begin{abstract}
Springtime urban road dust forms one of the most serious problems regarding air pollution in Finland. The composition and origin of springtime dust was studied in southern Finland with two different methods. Suspended particles ( $\mathrm{PM}_{10}$ and TSP) were collected with high volume particle samplers and particle deposition was collected with moss bags. The composition of the $\mathrm{PM}_{1.5-10}$ fraction was studied using individual particle analysis with SEM/EDX. The deposition in the moss bags was analysed with ICP-MS. The results showed that during the study period, approximately $10 \%$ of both $\mathrm{PM}_{1.5-10}$ particles and the deposition originated from sanding. Other sources in the springtime $\mathrm{PM}_{1.5-10}$ were e.g. asphalt aggregate or soil and combustion processes. It can be concluded that sanding produced a relatively small amount of particulate matter under the investigated circumstances.
\end{abstract}

Keywords: deposition, fugitive dust, mineral dust, moss bag method, paved roads, $\mathrm{PM}_{10}$, SEM/EDX, studded tires, traction sanding

\section{Introduction}

In areas with cold winter climate a special air pollution problem exists. Particulate matter accumulates in the urban environment over the winter months. When the snow melts, the particles concentrated in the snow are suspended to the air. In the urban areas the $\mathrm{PM}_{10}$ levels rise drastically especially near roads with dense traffic when road surfaces dry out (Kukkonen et al., 1999; Pakkanen, Loukkola et al., 2001; Pakkanen, Kerminen et al., 2001). Special meteorological conditions like ground based low-height inversion with low wind speeds are often related with the high PM concentrations (Pohjola et al., 2000).

Mineral dust forms usually a major part of the PM of the springtime episodes (Ojanen et al., 1998; Pakkanen, Loukkola et al., 2001). The two main sources of mineral dust in the urban areas during winter are: asphalt aggregate worn by the winter tires and traction sand (Hosiokangas et al., 1999; Kukkonen et al., 1999). Winter tires are compulsory in motor vehicles during the winter months in Finland and approximately $90 \%$ of cars have winter tires that are equipped with metal studs. To further promote traffic safety sand is commonly applied on streets and roads after snowstorms. Also de-icing salt is used to prevent road slipperiness. 
To estimate the shares of the different mineral dust sources, like traction sand and asphalt aggregate is difficult, because the rock aggregates often have a similar chemical composition (Song et al., 1999). There are several factors that have an impact on the source contribution but very few studies exist. The shares of the different sources are affected by the amount of traffic, the speed limit, the amount of sand dispersed on the road and the share of studded tires in the traffic flow. The actual wearing process of the road surface is affected by the design of the tire and the studs. According to Lampinen (1993) the most important stud properties affecting the wear are: stud mass, protrusion of the stud, the studs' impact energy and the area of spike impact. Wearing occurs also because of the grinding effect of the sand material under the tire (Kanzaki \& Fukuda, 1993, Lindgren, 1998). Some rocks resist the wearing processes better than others, so the morphologies and the mineralogy of the pavement and sanding aggregates have an effect on the source shares.

In Japan studded tires were banned in the beginning of 1990's largely because of the dust emissions. Fukuzaki et al. (1986) and Amemiya et al. (1984) concluded that during spring the levels of particulate matter in the ambient air were highest in areas where studded tires were used. Noguchi et al. (1995) reported that in Japan after the ban of studded tires, the overall dust concentrations and the road pavement derived alkaline dust in precipitation have declined. These studies did not report the use of traction sanding. Also in some states of the United States of America studs are prohibited. The benefits and setbacks of the use of studded tires and traction sanding have been discussed also in Scandinavia. In an American study, Kantamaneni et al. (1996) observed $40 \%$ higher $\mathrm{PM}_{10}$ emissions from a sanded road compared to an unsanded one. However, they did not report the use of studded tires.

Another interest towards the composition and sources of the springtime dust rises from the new EU limit values for airborne particles. If the EU limit values given in the Council Directive 1999/30/EC for thoracic particles $\left(\mathrm{PM}_{10}\right)$ are exceeded, member states must implement action plans in accordance with Council Directive 1996/62/EC for attaining the limit value within a specific time limit. However, the member states can designate the zones within which the limit values are exceeded due to the resuspension of particulates following the winter sanding of roads (Council Directive 1999/30/EC, article 5). A list of such areas must be provided with information of concentrations and sources of $\mathrm{PM}_{10}$. It must be shown that the exceedances are due to road sanding and that reasonable measures have been taken to lower the concentrations. In Finland the $\mathrm{PM}_{10}$-concentrations have exceeded the national guide values (Table I) largely because of the springtime mineral dust (Kukkonen et al., 1999) and there is a risk that also the new limit values will be exceeded especially when the stricter second phase will be implemented in 2010 (Table II).

The aim of this study was to estimate the share of the sanding component in the suspended particles in a situation where both studded tires and traction sand are in 
TABLE I

The Finnish guide values for TSP and $\mathrm{PM}_{10}$

\begin{tabular}{lclll}
\hline $\begin{array}{l}\text { The Finnish } \\
\text { guide values }\end{array}$ & $\begin{array}{l}\text { Daily } \\
\left(\mu \mathrm{g} \mathrm{m}^{-3}\right)\end{array}$ & $\begin{array}{l}\text { Statistical } \\
\text { definition }\end{array}$ & $\begin{array}{l}\text { Annual } \\
\left(\mu \mathrm{g} \mathrm{m}^{-3}\right)\end{array}$ & $\begin{array}{l}\text { Statistical } \\
\text { definition }\end{array}$ \\
\hline $\mathrm{PM}_{10}$ & 70 & $\begin{array}{l}\text { second highest daily } \\
\text { value of the month }\end{array}$ & - & - \\
TSP & 120 & $\begin{array}{l}\text { 98. percentile of } \\
\text { the data }\end{array}$ & 50 & $\begin{array}{l}\text { arithmetic mean of } \\
\text { daily mean values in a year }\end{array}$ \\
\hline
\end{tabular}

TABLE II

The EU limit values for $\mathrm{PM}_{10}$ which are implemented in two stages

\begin{tabular}{llll}
\hline $\begin{array}{l}\text { EU limit values } \\
\left(\mathrm{PM}_{10}\right)\end{array}$ & $\begin{array}{l}\text { Daily } \\
\left(\mu \mathrm{g} \mathrm{m}^{-3}\right)\end{array}$ & $\begin{array}{l}\text { Number of } \\
\text { exceedances allowed }\end{array}$ & $\begin{array}{l}\text { Annual } \\
\left(\mu \mathrm{g} \mathrm{m}^{-3}\right)\end{array}$ \\
\hline 2005 & 50 & 35 & 40 \\
2010 & 50 & 7 & 20 \\
\hline
\end{tabular}

use. Estimations of other possible sources in the springtime dust were also made. The shares were estimated from ambient particles with individual particle analysis with SEM/EDX and from deposition samples with bulk analysis with ICP-MS

\section{Materials and Methods}

In the city of Hanko a special material was used for winter sanding of roads, namely clinker from a nearby iron factory. The elemental composition (XRF-analysis) was received from the laboratory of the Rautaruukki Group. The clinker has high contents of $\mathrm{Ca}$ and $\mathrm{Mg}$ but very little Fe (Table III). The Ca-, Fe- and Mg-content of 4 clinker samples was additionally analysed with AAS (Varian SpectrAA 300/400) using $\mathrm{HNO}_{3}$-digestion similarly as in the analysis of the moss bags (see Section 2.2). The maximum concentration in the blank samples was less than $1 \%$ of the lowest clinker sample. During the winter 1999-2000, approximately $15-20 \mathrm{t} \mathrm{km}^{-1}$ of clinker sand was dispersed on the roads of Hanko and its influence was clearly detected in the chemistry of the local dust (See section 3.3). 
TABLE III

The $\mathrm{Ca}, \mathrm{Fe}$ and $\mathrm{Mg}$ concentrations (\%) of the clinker analysed with AAS and XRF. SD calculated from 4 duplicates

\begin{tabular}{lrrr}
\hline & \multicolumn{2}{c}{ AAS } & XRF \\
\cline { 2 - 4 } & \multicolumn{1}{c}{ S } & \multicolumn{1}{c}{ SD } & \multicolumn{1}{c}{} \\
\hline $\mathrm{Ca}$ & 24.1 & 0.4 & 26.6 \\
$\mathrm{Fe}$ & 0.4 & 0.1 & 0.4 \\
$\mathrm{Mg}$ & 7.2 & 0.2 & 8.1 \\
\hline
\end{tabular}

\subsection{TSP AND PM TO $_{10}$ COLLECTION WITH HIGH-VOLUME SAMPLERS IN HANKO AND ANALYSIS WITH SEM/EDX}

During the spring 2000, ambient particles were collected with two high-volume particle samplers (TSP - Kimoto, and $\mathrm{PM}_{10}$ - gravimetric Wedding \& Associates Sampler) in the city of Hanko. The samplers were placed by a paved road with an average traffic flow of 5,500 vehicles per day. The equipment was placed at a distance of $3 \mathrm{~m}$ from the road side at a height of $4 \mathrm{~m}$. Particles were collected on glass fibre filters in 3-day periods, altogether nine filters from both devices. The particle concentration was measured gravimetrically.

The elemental composition of individual particles was studied from the $\mathrm{PM}_{10}$ samples with a scanning electron microscope (SEM - ZEISS DSM 962) coupled with an energy dispersive X-ray microanalyzer (EDX - LINK ISIS with ZAF-4 measurement program). This instrumentation has been used in several individual particle studies (e.g. Mamane et al., 1980; Kasparian et al., 1998; Ganor et al., 1998; Paoletti et al., 1999; Haapala \& Kikuchi, 2000; Breed et al., 2002; Paoletti et al., 2002). The SEM/EDX samples were mounted on an aluminium stub by attaching the filter surface covered with particles, on a double sided tape (Scotch Ruban Adhesive) (Breed et al., 2002). A minimum of two samples from each filter was made. The samples were coated with carbon (Agar SEM Carbon Coater) to make the sample surface conductive (e.g. Katrinak et al., 1995; Jones et al., 2001; Paoletti et al., 2002). The accelerating voltage was $20 \mathrm{kV}$. The total X-ray count rate was calibrated with cobalt to approximately 1500 counts $\mathrm{s}^{-1}$. From each particle an X-ray spectrum was collected with a preset time of $15 \mathrm{~s}$.

The minimum geometric diameter for the analysed particles was 1.5 micrometers. This was thought to be the lowest limit to obtain reliable results from individual particles with this technique (Jambers et al., 1995). Such a limit did not cause problems for the study because the main focus was in the coarse mode mineral particles. 
THE EFFECT OF TRACTION SANDING ON URBAN SUSPENDED PARTICLES IN FINLAND 291

TABLE IV

The most abundant particle types and their main elements (oxygen excluded)

\begin{tabular}{|c|c|c|c|c|c|c|c|c|c|}
\hline & $\mathrm{Al}$ & $\mathrm{Ca}$ & $\mathrm{Fe}$ & $\mathrm{K}$ & $\mathrm{Mg}$ & $\mathrm{Na}$ & S & $\mathrm{Si}$ & $\mathrm{Ti}$ \\
\hline Quartz & & & & & & & & $\mathrm{X}$ & \\
\hline Plagioclase feldspar & $\mathrm{X}$ & $\mathrm{X}$ & & & & $\mathrm{X}$ & & $\mathrm{X}$ & \\
\hline Potassium feldspar & $\mathrm{X}$ & & & $X$ & & & & $\mathrm{X}$ & \\
\hline Biotite & $\mathrm{X}$ & & $\mathrm{X}$ & $\mathrm{X}$ & $X$ & & & $X$ & $\mathrm{X}$ \\
\hline Amfibols & $\mathrm{X}$ & $\mathrm{X}$ & $\mathrm{X}$ & & $\mathrm{X}$ & $\mathrm{X}$ & & $\mathrm{X}$ & \\
\hline Clinker & $\mathrm{X}$ & $\mathrm{X}$ & & & $\mathrm{X}$ & & $\mathrm{X}$ & $\mathrm{X}$ & \\
\hline $\begin{array}{l}\text { Fly ash/asphalt } \\
\text { filler/tire dust }\end{array}$ & $\mathrm{X}$ & $X$ & $\mathrm{X}$ & $\mathrm{X}$ & $X$ & $X$ & $\mathrm{X}$ & $\mathrm{X}$ & $\mathrm{X}$ \\
\hline
\end{tabular}

a also carbon was observed.

From all $9 \mathrm{PM}_{10}$-filters altogether 971 individual particles were analysed with SEM/EDX. From each filter a minimum of 100 randomly picked particles were analysed with EDX and the elemental weight percentages for each particle were calculated with $\mathrm{ZAF}$ for $\mathrm{Al}, \mathrm{Ca}, \mathrm{Cl}, \mathrm{Fe}, \mathrm{K}, \mathrm{Mg}, \mathrm{Na}, \mathrm{O}, \mathrm{S}, \mathrm{Si}$, and Ti. If other elements were observed, they were also recorded. It is important to note that ammonium compounds are not included because of the poor efficiency of the EDX in detecting nitrogen and because ammonium nitrate particles are volatile and may be lost in the vacuum of the SEM (Katrinak et al., 1995; Kasparian et al., 1998; Paoletti et al., 2002). Similar approach has been used in airborne particulate studies by Paoletti et al. (1999 and 2002) and Breed et al. (2002). To obtain 'fingerprints' for comparison, separate samples of the filler material of asphalt, and the clinker sand were crushed to dust and a SEM/EDX-sample was prepared similarly as from the airborne samples.

Particles were classified according to their elemental combinations. Observed particle types and their main elements are shown in Table IV. The 'fingerprints', local mineralogy and earlier studies were used as a basis for the classification. Katrinak et al. (1995) have estimated the relative errors of the ZAF-procedure for the atomic fractions observed in the individual particles to be 10-20\%. Because of the inaccuracies of the quantitative analysis method (ZAF) the weight percentages were used more in a semi-quantitative way: the elements with a weight percentage of over $1 \%$ were considered present (see Hoornaert et al., 1996).

\subsection{Deposition COLLECTION With MOSS BAGS IN HANKO AND TAMMISAARI AND ANALYSIS WITH ICP-MS}

Particle deposition was collected with the moss-bag method (see Little \& Martin, 1974; Vasconcelos \& Tavares, 1998) in Hanko and Tammisaari. They are neighbouring towns having similar population $(10,000-15,000)$, similar traffic and other 
conditions relevant for this research. The difference was in the sanding material. The city of Hanko used clinker sand while in Tammisaari, a 'normal' ground stone material was used. The composition of the deposition in these two cities was analysed to see the effect of the clinker sand on the chemistry of the dust. The main focus was on $\mathrm{Ca}$ and $\mathrm{Mg}$ since they were present in high concentrations in the clinker.

The moss material (Sphagnum girgensohnii) was collected from a non-polluted bog in southern Finland and prepared according to the Finnish standard (Finnish Standards Association, 1994). The moss bags were placed at the height of $2.5 \mathrm{~m}$, in Hanko by the same road as the samplers, and in Tammisaari in a similar location. There were 3 roadside sampling points in Hanko and 2 in Tammisaari. The bags were placed to the sites on March 17th 2000, and the samples were collected after 2,4 , and 6 weeks.

The sample bags were dried in $60{ }^{\circ} \mathrm{C}$ for $24 \mathrm{hr}$. For element analysis, approximately $0.3 \mathrm{~g}$ of dry homogenised moss matter was weighed to Teflon vessels and digested with $6 \mathrm{ml}$ of nitric acid (BDH Aristar, $\left.69 \% \mathrm{HNO}_{3}\right)$ and hydrogen peroxide (Merck Perhydrol 30\% $\mathrm{H}_{2} \mathrm{O}_{2}$ ) (5:1) and heated with a Milestone Ethos 1600-microwave. The concentrations of Al, B, Ba, Ca, Cr, Cu, Fe, K, Li, Mg, Mn, $\mathrm{Na}, \mathrm{Ni}, \mathrm{Pb}, \mathrm{Sr}, \mathrm{Zn}$ were measured by a Perkin-Elmer Elan 6000 ICP-MS. This paper concentrates on the results on $\mathrm{Ca}, \mathrm{Fe}$ and $\mathrm{Mg}$, which were the indicator elements for the purpose of this study. The ash content of the samples was measured by burning dry homogenised moss in $500^{\circ} \mathrm{C}$ for $4 \mathrm{hr}$. Each sample was prepared and measured in duplicate. The mean element concentrations $\left(\mu \mathrm{g} \mathrm{g}^{-1}\right)$ of the blank moss bags with standard deviation were 239 (SD 23) $\mathrm{Ca}, 132$ (SD 30) Fe and 32 (SD 2) Mg. The statistical calculations were performed with the Statistix 7 programme.

\section{Results and Discussion}

\subsection{VERnAL ROAD DUST EPISODE}

A particle episode was observed in Hanko in the spring 2000 (29th March, Figure 1). The daily national TSP guide value $\left(120 \mu \mathrm{g} \mathrm{m}^{-3}\right)$ was exceeded $\left(208 \mu \mathrm{g} \mathrm{m}^{-3}\right)$. The national $\mathrm{PM}_{10}$ guide value $\left(70 \mu \mathrm{g} \mathrm{m}^{-3}\right)$ was not exceeded. The mean temperature in Hanko during the study was $0.3{ }^{\circ} \mathrm{C}\left(\max 7.1^{\circ} \mathrm{C}\right.$ and $\left.\min -6.4^{\circ} \mathrm{C}\right)$ and the amount of precipitation during the study was approximately $50 \mathrm{~mm}$. Only moderate winds were observed (mean wind velocity 5-6 $\mathrm{m} \mathrm{s}^{-1}$ ). In March, over 50\% of the winds were from SW-NW. In April the easterly winds (NE-SE) dominated (Finnish Meteorological Institute, 2000a and 2000b). 


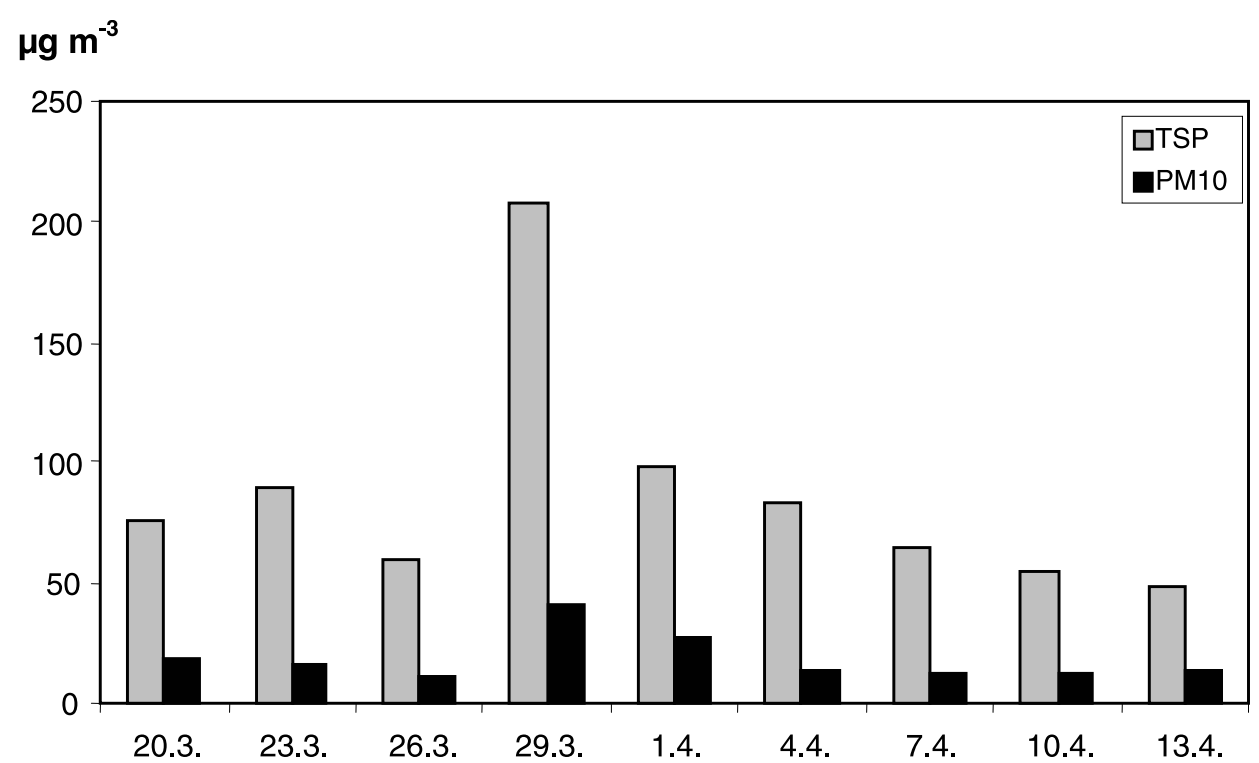

Figure 1. Mass concentrations for $\mathrm{PM}_{10}$ and TSP in Hanko. The mean values of three days, the last day marked on $\mathrm{x}$-axis.

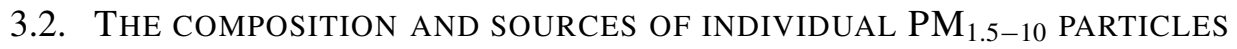 IN HANKO}

The filters were divided into three classes: before (March 17-23, 2000), during (March 27 to April 1, 2000) and after (April 2-13, 2000) the episode. From each period over 300 individual particles were analysed. The observed particle types are shown in Table IV. The abundances (\%) of the particle types were counted from the total number of the individual inorganic $\mathrm{PM}_{1.5-10}$ particles analysed with the SEM/EDX (see section 2.1). The shares are given in Table V, with standard deviation calculated from the subsamples. Possible sources of the particle classes were estimated and thus source contributions were assessed, shown in Figure 2. It should be noted that particles with carbon as the main component were left out of the study because of analytical problems (possible influence of carbon coating and carbon tape) and because the main focus was on inorganic particles. Based on analyses of two $\mathrm{PM}_{10}$ filters, the possible share of carbon particles in $\mathrm{PM}_{1.5-10}$ particles was estimated to be approximately $10 \%$ of the total number of particles.

The sanding-class consisted of the particles originating from the clinker sand that was used for winter sanding of the roads. The SEM/EDX-analyses showed that the clinker is relatively homogenous with a specific elemental composition shown in Table IV. The shape of the clinker particles was typically angular. The share of this particle class was approximately $10 \%$ of the total number of $\mathrm{PM}_{1.5-10^{-}}$ particles, showing a decreasing trend during the study period. 
TABLE V

The abundance $(\%)$ of the different inorganic particle types in the total number of the $\mathrm{PM}_{1.5-10}$ with standard deviation before, during and after the particle episode

\begin{tabular}{|c|c|c|c|c|c|c|}
\hline \multirow[t]{2}{*}{$\mathrm{PM}_{1.5-10}$} & \multicolumn{2}{|c|}{ March 17th -26 th } & \multicolumn{2}{|c|}{ March 27th - April 1st } & \multicolumn{2}{|c|}{ April 2nd - 13th } \\
\hline & Mean $\%$ & SD & Mean \% & SD & Mean $\%$ & SD \\
\hline Clinker & 12 & 1.2 & 11 & 1.7 & 6.3 & 5.1 \\
\hline Amfibols & 3.0 & 1.2 & 1.7 & 0.6 & 3.5 & 0.8 \\
\hline Biotite & 2.7 & 1.2 & 2 & 2.1 & 3.3 & 0.5 \\
\hline Potassium feldspar & 14 & 1.5 & 13 & 1.0 & 11 & 1 \\
\hline Plagioclase feldspar & 20 & 0 & 24 & 4.5 & 22 & 9.1 \\
\hline Quartz & 10 & 3.1 & 13 & 0.6 & 9.3 & 3.3 \\
\hline $\begin{array}{l}\text { Fly ash/asphalt } \\
\text { filler tire dust }\end{array}$ & 21 & 2.3 & 30 & 4.6 & 30 & 2.4 \\
\hline Other & 17 & 1.0 & 11 & 0.6 & 17 & 0.8 \\
\hline
\end{tabular}

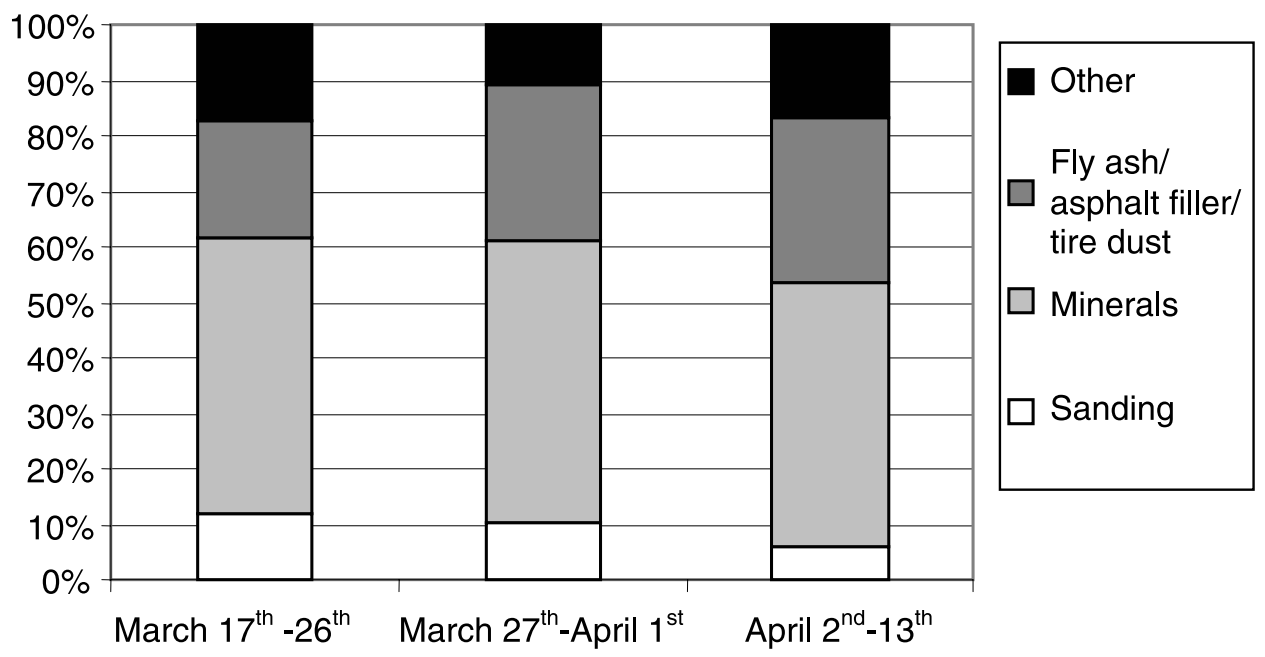

Figure 2. The abundance (\%) of the different sources in the total number of the inorganic $\mathrm{PM}_{1.5-10}$ particles before, during and after the particle episode.

The particles in the minerals-class made up to $50 \%$ of the inorganic $\mathrm{PM}_{1.5-10^{-}}$ particles. They are minerals or mineral groups that are common in the Finnish bedrock like quartz, plagioclase feldspar, potassium feldspar, biotite and amfibols. They were angular in shape and were assumed to originate mainly from the stone material of the asphalt. Other soil sources may also have some contribution to this mineral particle class, namely particles from local unpaved roads (see Claiborn $e t$ 
al., 1995), as well as from the unpaved shoulders of the studied road (Moosmüller et al., 1998).

Some of the particles were assumed to originate mainly from combustion sources or asphalt filler (with $\mathrm{C}$ and $\mathrm{S}$ from bitumen). Also tire dust has been reported to have similar composition (Rauterberg-Wulff et al., 1995; Camatini et al., 2001). This class made up to $20-30 \%$ of the inorganic $\mathrm{PM}_{1.5-10}$-particles (Table V, Figure 2). It was not possible to identify separately these sources. Their chemical composition resembled also that of fly ash from different combustion sources (see Ganor et al., 1998; Valmari et al., 1999; Lighty et al., 2000), and on the other hand that of bitumen mixed with minerals possibly from filler or stone materials of the asphalt, based on analysis made for this study. The fly ash can originate from the residential area where the houses are heated mainly with oil and wood. The shape of the particles varied between angular and roundy forms. Also agglomerates of roundy particles were observed. However, coarse spherical particles usually found in fly ash (Kindratenko et al., 1994; Xie et al., 1994) were not present. On the other hand the temperature for the formation of compact spherical particles may not have been high enough (Valmari et al., 1999) in the residential boilers. Some of the particles might also have been agglomerates of mineral particles that had been 'contaminated' e.g. through coagulation with carbon or sulphur bearing particles (Maname et al., 1980) or by gaseous compounds through heterogenous nucleation.

Class other particles contained particles, which were observed in small quantities, and those whose origin could not be identified. This class included sea salt particles, as well as $\mathrm{Na}_{2} \mathrm{SO}_{4}$-particles, which might be originally sea salt, in which $\mathrm{Cl}$ has been substituted by $\mathrm{SO}_{4}$ in the atmosphere (Kerminen et al., 1997; Song $\&$ Carmichael, 1998). Ca-S-O-particles were most likely $\mathrm{CaSO}_{4}$, which can be of combustion origin or formed in the atmosphere from $\mathrm{CaCO}_{3}$ (Hoornaert et al., 1996; Mori et al., 1998; Song and Carmichael, 1999). $\mathrm{CaCO}_{3}$-particles could originate from concrete materials (De Miguel et al., 1997) or from the filler material of asphalt (Hoornaert et al., 1996). Particles with high iron content most probably originate from wearing and corrosion of the metal surfaces and brakes (Garg et al., 2000). It is important to note that ammonium particles could not be included due to analytical reasons (see Section 2.1). Particle class 'other' made up about $15 \%$ of the inorganic $\mathrm{PM}_{1.5-10}$.

As a conclusion from the individual particle analysis with SEM/EDX, the share of particles from traction sanding was approximately $10 \%$ from the number of all inorganic $\mathrm{PM}_{1.5-10}$ particles and $17 \%$ from the number of all $\mathrm{PM}_{1.5-10}$ mineral particles.

\subsection{THE CONTRIBUTION OF CLINKER SAND ON THE ROADSIDE DUST DEPOSITION}

In order to get more information about the role of winter sanding material in vernal dust, we made comparative investigations of the dust in Hanko and Tam- 


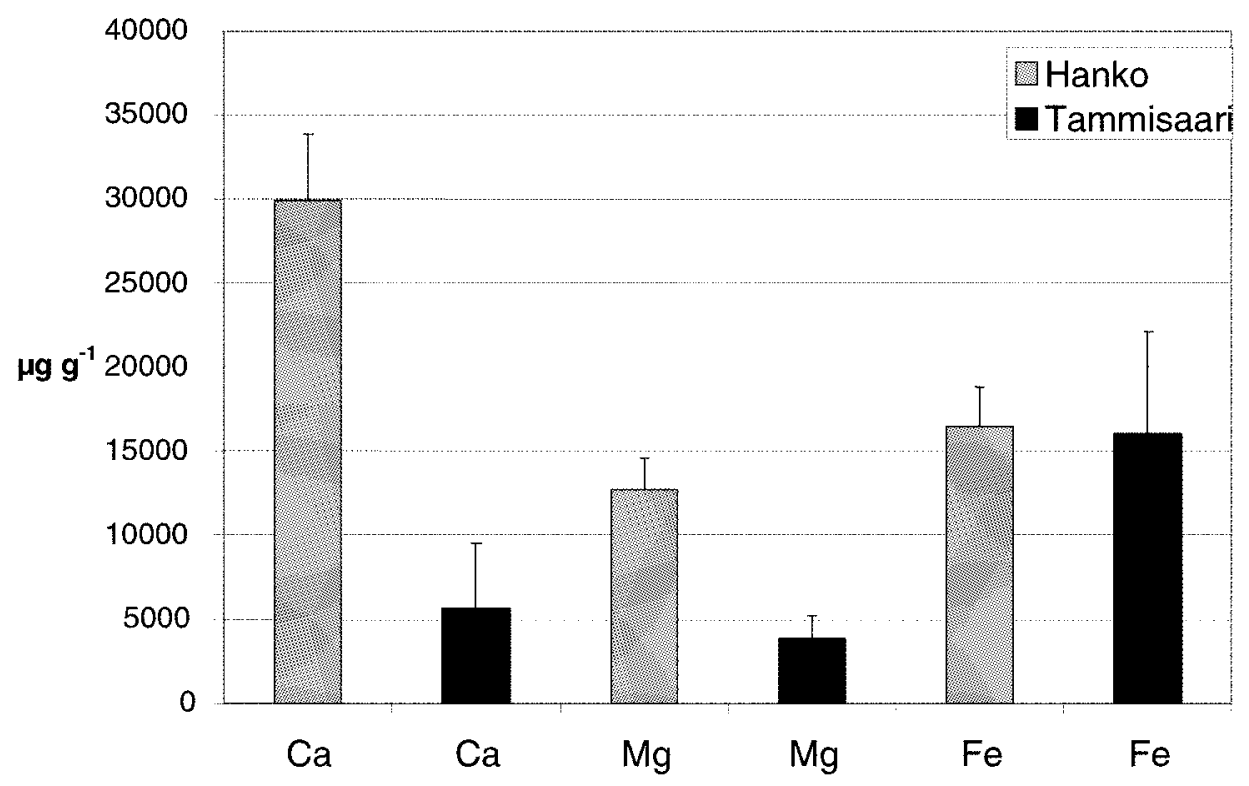

Figure 3. Accumulated $\mathrm{Ca}, \mathrm{Fe}$ and $\mathrm{Mg}$ in the ash of moss-bags in Hanko and Tammisaari with standard deviations.

misaari. Road dust deposition was collected with moss bags, and the elemental and ash concentrations of the bags were analysed. The ash content represents the amount of dust accumulated in the moss bag. The measured elemental concentrations $\left(\mu \mathrm{g} \mathrm{g}^{-1}\right)$ of the moss bags were divided with the ash content $\left(\mathrm{g} \mathrm{g}^{-1}\right)$ to get the concentrations $\left(\mu \mathrm{g} \mathrm{g}^{-1}\right)$ in the dust.

The concentrations of $\mathrm{Ca}, \mathrm{Mg}$ and $\mathrm{Fe}$ in the dust $\left(\mathrm{C}_{\mathrm{tot}}\right)$ are given in Figure 3. The results in Figure 3 are averages of 9 moss bags in Hanko and 6 in Tammisaari. The statistical analysis (Rank Sum Test) showed that the amounts of $\mathrm{Ca}$ and $\mathrm{Mg}$ in the dust were significantly higher in Hanko than in Tammisaari $(p=0.0002$ for both metals). Fe did not show any significant difference $(p=0.228)$. The only big difference in the sources of these two cities was the traction sanding material. It was shown that the clinker sand that was used for traction sanding in Hanko, has high concentrations of $\mathrm{Ca}$ and $\mathrm{Mg}$ (see Section 2.). Thus the excess $\mathrm{Ca}$ and $\mathrm{Mg}$ have to originate from the clinker. The concentrations measured from the Tammisaari moss bags represent the composition of the dust from other sources than the clinker sand.

A simple mass balance approach based on the measured concentrations (Equations 1-3) was used for estimating the share (X, \%) of the clinker sand in the dust deposition of Hanko. The concentrations of $\mathrm{Ca}$ and $\mathrm{Mg}$ in the dust $\left(\mathrm{C}_{\text {tot }}\right)$ (Figure 3) as well as the measured concentrations of these elements in Tammisaari $\left(\mathrm{C}_{\mathrm{T}}\right)$ and in the clinker sand $\left(\mathrm{C}_{\mathrm{S}}\right)$ were used for calculations.

$$
\mathrm{C}_{\mathrm{tot}}=\mathrm{C}_{\mathrm{S}} * \mathrm{X} \%+\mathrm{C}_{\mathrm{T}} *(100-\mathrm{X}) \%
$$


TABLE VI

The values used in the calculations (Equations 1-3) and the results for the share of dust from road sanding

\begin{tabular}{lllll}
\hline & $\begin{array}{l}\mathrm{C}_{\text {tot }} \\
\left(\mu \mathrm{g} \mathrm{g}^{-1}\right)\end{array}$ & $\begin{array}{l}\mathrm{C}_{\mathrm{S}} \\
\left(\mu \mathrm{g} \mathrm{g}^{-1}\right)\end{array}$ & $\begin{array}{l}\mathrm{C}_{\mathrm{T}} \\
\left(\mu \mathrm{gg}^{-1}\right)\end{array}$ & $\begin{array}{l}\mathrm{X} \\
(\% \text { from sanding })\end{array}$ \\
\hline $\mathrm{Ca}$ & 29900 & 241000 & 5680 & 10 \\
$\mathrm{Mg}$ & 12600 & 72000 & 3800 & 13 \\
\hline
\end{tabular}

$$
\begin{aligned}
& \mathrm{C}_{\text {tot }}=\mathrm{C}_{\mathrm{S}} * \mathrm{X} / 100+\mathrm{C}_{\mathrm{T}} *[(100-\mathrm{X}) / 100] \\
& \mathrm{X}=\left[\left(\mathrm{C}_{\mathrm{tot}}-\mathrm{C}_{\mathrm{T}}\right) /\left(\mathrm{C}_{\mathrm{S}}-\mathrm{C}_{\mathrm{T}}\right)\right]^{* 100}
\end{aligned}
$$

$\mathrm{C}_{\mathrm{tot}}=$ concentration of the element in the dust $\left(\mu \mathrm{g} \mathrm{g}^{-1}\right)$

$\mathrm{C}_{\mathrm{S}}=$ concentration of the element in the dust caused by the clinker sand $\left(\mu \mathrm{g} \mathrm{g}^{-1}\right)$ $\mathrm{C}_{\mathrm{T}}=$ concentration of the element in the dust caused by other sources $\left(\mu \mathrm{g} \mathrm{g}^{-1}\right)$ $\mathrm{X}=$ percentage from clinker sand

The values of $\mathrm{C}_{\mathrm{tot}}, \mathrm{C}_{\mathrm{T}}$ and $\mathrm{C}_{\mathrm{S}}$ used in the calculations and the share of the clinker, $\mathrm{X}$ are shown in Table VI. These results support the SEM/EDX studies, according to which about $10 \%$ of the total number of the inorganic $\mathrm{PM}_{1.5-10}$ particles was from the sanding material. It is important to notice that the two quite different sampling and analysing methods gave similar results.

\section{Conclusions}

A special traction sanding material, clinker sand made it possible to estimate the contribution of the traction sand to road dust. SEM/EDX was used for classifying and quantifying the particles collected by a high-volume sampler, and to identify the origins of the particles. Moss bag method was used for collecting roadside particle deposition and ICP-MS for analysing its elemental composition. Both methods gave similar results, indicating that about $10 \%$ of the vernal road dust originated from the sanding material. A more significant share was from other sources.

The national guide value for TSP was exceeded during the studied springtime road dust episode in the coastal Finnish town Hanko. The results showed that only a minor part of the exceedance resulted directly from the sanding material. However, there are many factors that can have a significant influence in the composition of the dust (e.g. the pavement wearing effect of the sand rocks depending on the properties and amount of the sanding and pavement aggregates, traffic, meteorology and the influence of other sources). These factors have been studied very little and more information about their importance is needed to effectively mitigate the emissions. 


\section{Acknowledgements}

This work is a part of the Finnish Research Programme MOBILE ${ }^{2}$, and has been funded by Tekes (the National Technology Agency), Ministry of Transport and Communications, and Helsinki University Licensing Oy. Valuable help in the field work was given by Marina Heino (Hanko Environment Centre), Gustav Munsterhjelm (Tammisaari Environment Centre), and Sammy Roiha (Envimetria Oy). SEM/EDX-investigations were performed at the Institute of Biotechnology, Electron Microscopy Unit, University of Helsinki. We thank Jyrki Juhanoja for technical advice. Moss bag analyses were performed at the Department of Limnology and Environmental Protection, Univ. Helsinki under the guidance of Esa Tulisalo. Pekka Kauppi (the Department of Limnology and Environmental Protection, Univ. Helsinki) gave us important and helpful comments about the early drafts of the text. We are also grateful to Hannu Silvennoinen (Nordic Envicon Oy), as well as to Päivi Aarnio and Tarja Koskentalo (Helsinki Metropolitan Area Council, Environmental Office) for valuable discussions and support during the work.

\section{References}

Amemiya, S., Tsurita, Y., Masuda, T., Asawa, A., Tanaka, K., Katoh, T., Mohri, M and Yamashina, T.: 1984, 'Investigation of environmental problems caused by studded tires of automobiles using PIXE', Nucl. Instruments Meth. Physics Res. B3, 516-521.

Breed, C. A., Arocena, J. M. and Sutherland, D.: 2002, 'Possible sources of $\mathrm{PM}_{10}$ in prince George (Canada) as revealed by morphology an in situ chemical composition of particulate', Atmos. Environ. 36, 1721-1731.

Camatini, M., Crosta, G. F., Dolukhanyan, T., Sung, C., Giuliani, G., Corbetta, G. M., Cencetti, S. and Regazzoni, C.: 2001, 'Microcharacterization and indentification of tire debis in heterogenous laboratory and environmental specimes', Mater. Character. 46, 271-283.

Claiborn, C., Mitra, A., Adams, G., Bamesberger, L., Allwine, G., Kantamaneni, R., Lamb, B. and Westberg, H.: 1995, 'Evaluation of PM10 emission rates from paved and unpaved roads using tracer techniques', Atmos. Environ. 29(10), 1075-1089.

De Miguel, E., Llamas, J. F., Chacón, E., Berg, T., Larssen, S., Røyset, O. and Vadset, M.: 1997, 'Origin and patterns of distribution of trace elements in street dust: unleaded petrol and urban lead', Atmos. Environ. 31(17), 2733-2740.

European Council Directive 1999/30/EC.

European Council Directive 1996/62/EC.

Finnish Meteorological Institute: 2000a, 'Climatic Survey, March 2000', Finnish Meteorological Institute, Helsinki, Finland.

Finnish Meteorological Institute: 2000b, 'Climatic Survey, April 2000', Finnish Meteorological Institute, Helsinki, Finland.

Finnish Standards Association: 1994, 'SFS 5794 Air Protection. Bioindication. Moss bag method', Finnish Standards Association SFS, Helsinki, Finland.

Fukuzaki, N., Yanaka, T. and Urushiyama, Y.: 1986, 'Effects of studded tires on roadside airborne dust pollution in Niigata, Japan', Atmos. Environ. 20(2), 377-386.

Ganor, E., Levin, Z. and Van Grieken, R.: 1998, 'Composition of individual aerosol particles above the Israelian Mediterranean coast during the summer time', Atmos. Environ. 32(9), 631-1642. 
Garg, B., Cadle, S., Mulawa, P. and Parr, G.: 2000, 'Brake wear particulate matter emissions', Environ. Sci. Technol. 34(21), 4463-4469.

Haapala, H. and Kikuchi, R.: 2000, 'Biomonitoring of the distribution of dust emissions by means of a new SEM/EDX technique', Environ. Sci. Pollut. Res. 7(4), 189-190.

Hoornaert, S., Van Malderen, H. and Van Grieken, R.: 1996, 'Gypsum and other calcium-rich aerosol particles above the North Sea', Environ. Sci. Technol. 30(5), 1515-1520.

Hosiokangas, J., Ruuskanen, J. and Pekkanen, J.: 1999, 'Effcts of soil dust episodes and mixed fuel sources on source apportionment of PM10 particles in Kuopio, Finland', Atmos. Environ. 33, $3821-3829$.

Jambers, W., De Bock, L. and Van Grieken, R.: 1995, 'Recent advances in the analysis of individual environmental particles, a review', Analyst 120, 681-692.

Jones, T., Williamson, B., BéruBé, K. and Richards, R.: 2001, 'Microscopy and chemistry of particles collected on TEOM filters: Swansea, South Wales, 1998-1999', Atmos. Environ. 35, 3573-3583.

Kantamaneni R., Adams G., Bamesberger L., Allwine E., Westberg H., Lamb B., Claiborn C.: 1996, 'The measurement of roadway $\mathrm{PM}_{10}$ emissions rates using atmospheric tracer ratio techniques', Atmos. Environ. 30(24), 4209-4223.

Kanzaki, H. and Fukuda, Y.: 1993, 'Reguations on Studded Tire Usage and Winter Road Administration in Japan', Proceedings of the International Workshop on Winter Road Management, Jan. 26-29. Sapporo, Japan, pp. 3-17.

Kasparian, J., Frejafon, E., Rambaldi, P., Yu, J., Vezin, B., Wolf, J. P., Ritter, P. and Viscardi, P.: 1998, 'Characterization of urban aerosols using SEM-microscopy, X-ray analysis and Lidar measurements', Atmos. Environ. 32(17), 2957-2967.

Katrinak, K., Anderson, J. and Buseck, P.: 1995, 'Individual particle types in the aerosol of Phoenix, Arizona', Environ. Sci. Technol. 29(2), 321-329.

Kerminen V-M., Pakkanen, T., Hillamo, R.: 1997, 'Interactions between inorganic trace gases and supermicrometer particles at a coastal site', Atmos. Environ. 31(17), 2753-2765.

Kindatrenko, V., Van Espen, P., Treiger, B. and Van Grieken, R.: 1994, 'Fractal dimensional classification of aerosol particles by computer-controlled scanning electron microscopy', Environ. Scim Technol. 28(12), 2197-2202.

Kukkonen, J., Salmi, T., Saari, H., Konttinen, M. and Karstasenpää, R.: 1999, 'Review of urban air quality in Finland', Boreal Environ. Res. 4, 55-65.

Lampinen, A.: 1993, 'Rutting of Pavements Caused by Studded Tyres', PhD thesis. Technical Centre of Finland, Espoo, Finland. (Abstract).

Lighty, S. J., Veranth, J. M. and Sarofim, A. F.: 2000, 'Combustion aerosols: Factors governing their size and composition and implications to human health', J. Air Waste Manage. Assoc. 50, $1565-1618$.

Lindgren, Å.: 1998, 'Road Construction Materials as a Source of Pollutants', PhD thesis, Luleå University of Technology, 05/1998. Luleå, Sweden. 129 pp.

Little, P. and Martin M.H.: 1974, 'Biological monitoring of heavy metal pollution', Environ. Pollut. 6, 1-19.

Mamane, Y., Ganor, E. and Donagi, A. E.: 1980, 'Aerosol composition of urban and desert origin in the eastern Mediterranean. I. Individual particle analysis', Water, Air, Soil Pollut. 14, 29-43.

Moosmüller, H., Gillies, J. A., Rogers, C. F., DuBois, D. W., Chow, J. C. and Watson, J. G.: 1998, 'Particulate emission rates for unpaved shoulders along a paved road', J. Air Waste Manage. Assoc. 48, 398-407.

Mori, I., Masataka, N. and Yasunobu, I.: 1998, 'Chemical reaction during the coagulation of ammonium sulphate and mineral particles in the atmosphere', Sci. Total Environ. 224, 87-91.

Noguchi, I., Kato, T., Akiyama, M., Otsuka, H. and Matsumoto, Y.: 1995, 'The effect of alkaline dust decline on the precipitation chemistry in northern Japan', Water, Air Soil Pollut. 85, 2357-2362.

Ojanen, C., Pakkanen, T., Aurela, M., Mäkelä, T., Meriläinen, J., Hillamo, R., Aarnio, P., Koskentalo, T., Hämekoski, K., Rantanen, L. and Lappi, M.: 1998, 'The Size-Distribution, Composition and 
Sources of Respirable Particles in the Helsinki Metropolitan Area', Helsinki Area Metropolitan Council, Report series C 1998:7, Helsinki, Finland. (In Finnish with English abstract).

Pakkanen, T. A., Loukkola, K., Ojanen, C., Korhonen, C., Aurela, M., Mäkelä, T., Hillamo, R. E., Aarnio, P., Koskentalo, T., Kousa, A. and Maenaut, W.: 2001, 'Sources an chemical composition of amospheric fine and coarse particles in the Helsinki area', Atmos. Environ. 35, 5381-5391.

Pakkanen, T. A., Kerminen, V-M., Korhonen, C. H., Hillamo, R. E., Aarnio, P., Koskentalo, T. and Maenhaut, W.: 2001, 'Use of atmospheric elemental size distributions in estimating aerosol sources in the Helsinki area', Atmos. Environ. 35, 5537-5551.

Paoletti, L., Diociaiuti, M., De Berardis, B., Santucci, S., Lozzi, L. and Picozzi, P.: 1999, 'Characterisation of aerosol individual particles in a controlled underground area', Atmos. Environ. 33, 3603-3611.

Paoletti, L., De Berardis, B. and Diociaiuti, M.: 2002. 'Physico-chemical characterization of the inhalable particulate matter (PM10) in an urban area: An analysis of the seasonal trend', Sci. Total Environ. 292, 265-275.

Pohjola, M., Kousa, A., Aarnio, P., Koskentalo, T., Kukkonen, J., Härkönen, J. and Karppinen, A.: 2000, 'Meteorological Interpretation of Measured Urban PM2.5 and PM10 Concentrations in the Helsinki Metropolitan Area', in J. W. S. Longhurst, C. A. Brebbia, and H. Power (eds), Air Pollution VIII. Wessex Institute of Technology Press, pp. 689-698.

Song, C. H. and Carmichael, G. R.: 1999, 'The aging process of naturally emitted aerosol (sea-salt and mineral aerosol) during long range transport', Atmos. Environ. 33, 2203-2218.

Song, X-H., Hadjiiski, L., Hopke, P. K., Ashbaugh, L. L., Carvacho, O., Casuccio, G. S. and Schlaegle, S.: 1999, 'Source apportionment of soil samples by the combination of two neural networks based on computer-controlled scanning electron mMicroscopy', J. Air Waste Manag. Assoc. 49, 773-783.

Valmari, T., Lind, T. M., Kauppinen, E. I., Sifris, G., Nilsson, K. and Maenhaut, W.: 1999, 'Field study on ash behavior during circulating fluidized-bed combustion of biomass. 1. Ash formation', Energy Fuels 13, 379-389.

Vasconcelos, M. T. S. D. and Tavares, H. M. F.: 1998, 'Atmospheric metal pollution (Cr, Cu, Fe, Mn, $\mathrm{Ni}, \mathrm{Pb}$ and $\mathrm{Zn}$ ) in Oporto city derived from results for low-volume aerosol samplers and for the moss Sphagnum auriculatum bioindicator', Sci. Total Environ. 212, 11-20.

Xie, Y., Hopke, P. K., Wienke, D.: 1994, 'Airborne particle classification with a combination of chemical composition and shape index utilizing an adaptive resonance artificial neural network', Environ. Sci. Technol. 28(11), 1921-1928. 